\title{
Translation in language teaching, pedagogical translation, and code-Switching: restructuring the boundaries
}

\section{Lucía Pintado Gutiérrez}

To cite this article: Lucía Pintado Gutiérrez (2021) Translation in language teaching, pedagogical translation, and code-Switching: restructuring the boundaries, The Language Learning Journal, 49:2, 219-239, DOI: 10.1080/09571736.2018.1534260

To link to this article: https://doi.org/10.1080/09571736.2018.1534260

曲 Published online: 15 Nov 2018.

Submit your article to this journal 준

山ll Article views: 1229

Q View related articles $\longleftarrow$

View Crossmark data ־

Citing articles: 8 View citing articles $\widetilde{ }$ 


\title{
Translation in language teaching, pedagogical translation, and code-Switching: restructuring the boundaries
}

\author{
Lucía Pintado Gutiérrez
}

School of Applied Language and Cultural Studies, Dublin City University, Dublin, Ireland

\begin{abstract}
The gradual reintroduction of translation into the foreign language classroom in the last few decades has generated considerable interest among teachers and scholars. A renewed focus on translation as an aspect of language teaching has simultaneously originated from and resulted in the publication of theoretical and empirical studies as well as monographs that recognise 'pedagogical translation' as a beneficial and increasingly accepted practice. However, conceptual and terminological inconsistencies persist that blur the boundaries between the general idea of using translation in the language classroom and more specific practices that involve translation tasks (also known as 'pedagogical translation') or code-switching. The article addresses these terminological incongruities by exploring the impact of conceptualisations of translation in language education and, specifically, its use in pedagogical translation. The goal is to consider the plethora of concepts related to translation in language teaching (TILT) and to explore how they may be connected with the reconceptualisation of translation in language pedagogy. This will open up useful avenues for a more thorough incorporation of translation into foreign language education, particularly at the secondary and college level, and will propose future lines of research and pedagogical sound praxis.
\end{abstract}

\section{KEYWORDS}

Pedagogical translation; translation in language teaching; translation studies; code-switching; foreign language teaching and learning; pedagogy

\section{Introduction}

The role of translation in the foreign language (FL) or second language $(\mathrm{L} 2)^{1}$ classroom has seen extensive reconsideration over the last few decades. Since the early 2000s, a significant increase in publications in this domain suggests its revitalisation as new approaches and conceptualisations of translation in the language classroom are being explored. Translation is emerging as a communicative activity abandoning the much-debated traditional notion of translation as a FL teaching method (Carreres 2014; Colina 2002; Pintado Gutiérrez 2012). In spite or perhaps because of this burgeoning interest, considerable inconsistencies exist among scholars, researchers, and teachers regarding its precise nature and status in the field. To begin with, although translation is often overlooked in the official FL curricula, it is used in the classrooms, as the Directorate-General for Translation (DGT) in the EU claims (2013). That situation necessitates, first, that we acknowledge the frequently ignored reality of quite different forms and types of translation in the language classroom thus clarifying one of the prime struggles: the meaning and the role of 'translation' in FL pedagogy. As Cook (2010: xix) reminds us, while translation in the FL classroom involves own language (or L1, also known as mother tongue and first language) use, such use of the L1 does not necessarily involve translation. Indeed, different types of translation are likely to refer to distinct phenomena and 
involve quite different principles and assumptions. In this article, I will use the term 'translation in language teaching' (borrowing Cook's acronym 'TILT') as a way of signalling a broader conceptualisation of the use of translation. Inasmuch as it refers to a variety of practices that use translation and communicative principles it is distinct from earlier conceptualisations of the use of translation in the language classroom. In line with this conception, I hope to be able to contribute not only to a redefinition of the boundaries and the terms related to translation in language teaching but more specifically to an exploration of the possible contribution in its own right of what is here referred to as pedagogical translation.

A second consideration is this: Because translation is inherently an interdisciplinary endeavour, the construct of pedagogical translation tends to borrow terminology from other fields in order to establish its theoretical and pragmatic frameworks. One negative consequence of such liberal borrowing is that any discussion of translation in language teaching is akin to 'traps for a writer on the topic to fall into' (Cook 2010: xxi). Among such traps is being seen as questioning the status quo of terms that are well established in applied linguistics, second language acquisition or translation studies. Rather than engaging in that precarious practice, my aim is to explore the meaning of key terms associated with translation in the FL classroom. Following a discussion on the terms currently used in literature, I propose a map of neighbouring concepts that ascertain a better understanding of the various terms related to translation and L1/L2 use in language pedagogy for a beneficial use of these practices.

This should enable a more forward-looking stance toward the use of translation in FL classrooms, particularly the possibility of a fuller, because reshaped understanding of pedagogical translation. A concluding comment is in order: Even as I deliberately steer clear of questioning the use of 'translation' in applied disciplines, applied linguistics itself has begun to reconsider how it has handled translation in the past and what adjustments might be necessary to capture the reality of language learning and use in a multilingual world (among other publications, see especially Wei 2011).

\section{Translation in language teaching: historical developments}

It is generally assumed that formal contributions from linguistics to FL teaching and learning began in the 1940s. Less developed is a narrative of the role and function of translation in this development. But as Howatt (1984) points out, attempts to arrive at a methodological consensus for a more precisely defined 'discipline' of language teaching began to be a possibility when 'the battles over "grammar" and "translation" were over, the dust had settled, and the most useful thing was to develop a modified "direct method" approach' (260). But things are rather less straightforward than that description suggests. Even when translation was 'officially' banned from the FL classroom, pedagogical reality was considerably more complex despite the overriding tenor for decades to come of considering translation to be a poisonous element in language pedagogy. That negative assessment is readily captured in the yoked term of grammar-translation method (McLaughlin 1987; Mitchell and Myles 2004) that identified a 'villain' (Cook 2010: 9) to be expelled from the classroom, most especially in its manifestation of interlingual translation or the use of students' mother tongue. The prevailing and unabashedly negative narrative against grammar-translation methods was to accuse them of focusing on grammar rules, structures, specific vocabulary, and formal equivalence, and to treat knowledge as 'cumulative and staged' (Cook 2010: 10). This imbued the rejected approach with a certain static and staged quality that could easily be traced to the practice of translating the classical 'dead' languages of Greek and Latin, a focus that presumably had little interest in contemporary agenda of fostering oral abilities, including interactive fluency.

While rejecting the grammar-translation method already denied any value for translation as part of language learning, there is another aspect to this rejection that deserves attention: As the forerunner of the direct method it also enshrined as highly desirable a strict monolingualism in the target language. As a result, 'intralingual teaching' (Stern 1992: 279) and 'monolingual teaching' (Widdownson 2003: 149) were set in opposition to 'crosslingual' and 'bilingual' teaching (Cook 2010: 7). In light 
of those positions, it is not surprising that the broad re-examination of monolingual principles in the language studies field in general and in language pedagogy in particular has ushered in a possible reintroduction of translation into the $\mathrm{FL}$ classroom. Strict notions of both monolingualism and even bilingualism are no longer relegated to the discipline's rejected past; rather, reflecting on them has enabled a rethinking and reassessment of the legitimacy of translation in contemporary FL teaching. It is worth noting that this shift is currently embraced by different 'turns' in various disciplines that favour revisiting translation in FL teaching and learning: (a) the multilingual turn, discussed by May (2014); (b) the pluricultural turn, highlighted by González Davies (2018); or (c) the translation turn proclaimed by Carreres et al. (2017). All these turns support exploring the pertinent question of an updated perspective of the use of translation where 'translation is certainly making a comeback that is far from Grammar-Translation practices' (in González Davies' Foreword to Carreres et al. 2017: xiii).

The 1940s saw a noteworthy surge in the opposition to using translation in FL pedagogy, particularly evident in the communicative era-even though negative stances against translation had already existed earlier in the century. This was a vivid testament to the fact that translation had been a staple of modern FL classrooms and had attained a certain 'institutionalized' presence in pedagogy-despite the importance to speak another language that was otherwise highlighted. It is only against this background that one can understand and appreciate the agenda of the Reform Movement (prioritising oral communication skills, contextualising grammar points in natural texts and allowing the use of the FL in class) and the popularity of Berlitz methods (disapproving L1 use and translation in the FL classroom, pursuing the 'spirit' of a FL and escaping a flawed equivalence between languages), which, according to Cook (2010), ultimately merged into what came to be known as the direct method.

And yet, after a period of seemingly unbridgeable enmity between 'acceptable' pedagogies and translation, the 1980s brought first hints of possible ways to reconcile the two camps. A prominent trigger for these first cautious steps toward rapprochement was provided by the need to explain the difference between professional translating and whatever forms translation took in the FL classroom. This can be traced in works on language pedagogy and translation studies such as Delisle (1980, 1998), Lavault (1985), and Grellet (1991). It is fair to say however that no all scholars advocated for a separation: Lavault's work for instance does not support an absolute divide between both modalities (1985: 107-109), and neither does Cordero (1984: 351). The effort in finding the identity of different types of translation was itself triggered by demands for improving the teaching of translation, a challenge that necessitated much more careful consideration of the kinds of pedagogies that would be required to train future professional translators and, implicitly, reflection on how they differed from what otherwise took place in classrooms. That this is by no means past history can be seen from the fact that, as recently as 2001, Baker stated that 'as an academic discipline, translation studies is relatively young' (277). Nevertheless one can witness a gradual consolidation of the discipline and, simultaneously, deeper reflection on whether and how translation might yet play a role-though presumably a quite different one-in FL pedagogy.

Not surprisingly, for some scholars, as discussed below, this meant drawing lines of strict separation between what were seen as two different disciplines, translation studies and FL teaching. By contrast, others detected an opportunity to rejuvenate an interest in translation in language pedagogy, though now conceived much more dynamically and responsive to the principles of communicative language teaching that came to prevail at the time. Different and frequently contradictory arguments and strands can be observed. For example, Cordero (1984) defended the insertion of translation in the FL curriculum in higher education as a tool through which students can learn to communicate. In so doing she drew another distinction —while creating a subtle and potentially troublesome argument: Translation as 'permissible' in the intellectually demanding environment of higher education, though, perhaps, not appropriate in L2 pedagogies with their full-throated interest in 'communication'. Thus, Cordero's claim that the lack of clarification in translation and its role in the FL classroom had important-and largely negative-repercussions was essential in revisiting this aspect: 
'Regretfully, much of the controversy of the place of translation in second language acquisition has been at cross-purposes, since the nature of translation is frequently misunderstood, and its function in the learning process not specified' (352). What followed this bold statement were first explorations for how one might go about restoring translation into language teaching, including most specifically questioning the praxis of using translation in pedagogies and, gradually, redefining boundaries that had previously been claimed to be well-nigh insurmountable, both theoretically and practically.

A quite different strategy for moving away from the dichotomy between professional translation studies and translation in FL pedagogy was adopted by Delisle (1980), whose work emphasizes the theory and didactics of translation. At the same time, she advocated pedagogical translation as a way of testing competence in a foreign language. As a result, while the rising disciplinary area of translation studies relegated translation to a secondary status in FL pedagogy, in a way it also fostered the potential for including it in forward-looking pedagogical approaches.

Another particularly important intellectual move in this regard was taken by Lavault (1985) who defined pedagogical translation (PT) as the didactic use of translation in language teaching $(9,18)$, which is in itself tautological in nature, and defended its use within an expanded framework of what she referred to as 'interpretative translation' (see especially 49-51), at times also as 'professional' or 'real translation'. From a strategic standpoint it is worth noting that she deliberately uses terminology 'that avoids (...) the use of overly specific vocabulary, which varies particularly according to different schools, both in general linguistics and in foreign language teaching' (10-11, my translation). This linkage marked an intellectual and empirical turning point for ushering in a deliberate and thoughtfully argued return of translation into the FL classroom.

Following various publications in the next three decades one can now observe a second wave of insightful treatments of pedagogical translation; it is characterised by taking a decidedly interdisciplinary and holistic perspective.

More than a decade after Lavault's publication Hurtado Albir (1999) introduced pedagogical translation as an applied branch within a conceptual map of translation studies as a discipline. While her focus was on the pedagogy of professional translation, the publication also became an important landmark in second language acquisition inasmuch as she reformulated Holmes's 1972 wellknown proposal for classifying the different areas that integrate translation studies: She created a space within the new philosophies for translation pedagogies that was specifically devoted to translation in the language classroom in a way that recognised the demands of communicative language teaching, referring to it as 'pedagogical translation' (1999: 11).

More recently, Cook (2010) explored in depth the development of translation in the language classroom (TILT). Specifically, he sees the revival of bilingualism in English teaching as a reason for investigating and revising the use of translation in the language classroom. Although his work is sensitive to the complex and oftentimes contentious nature of translation in the FL classroom, it pays insufficient attention to the distinction between the use of the student's mother tongue in the FL classroom (often not involving translation) and translation as an actual classroom activity. At first sight, such a treatment has the advantage of seeing translation and L1 use as part of a continuum. At the same time, it blurs distinctions that are important not for the sake of creating boundaries but because they enable those who wish to implement TILT to begin to appreciate it as a tool, a strategy, and as a skill, and because such a practice can ward off future misinterpretation of the construct. As Hall and Cook (2012) express, stretching notions of translation to include own-language can 'cause severe confusion; different terms are often used by different authors to refer to the same concept, while the same terms are also used in different senses. Clarity is therefore needed' (273). By comparison, Leonardi (2010) analyses the different possibilities of pedagogical translation in the classroom developing her framework mostly on the basis of theories of second language acquisition, applied linguistics, and translation as these might relate to the classroom. Despite the controversy raised by the 'spectre' of translation in the FL classroom she views it positively: '(if) translation is employed for pedagogical purposes ... it can prove to be a useful aid aimed at teaching and learning foreign languages' (81). Laviosa (2014) proposes what she terms 'pedagogic translation' understood as a 
translation-based approach to FL pedagogy. This new orientation is framed in light of some of the latest trends and research on translation studies, while also taking account of recent insights gained in the field of translation in language teaching. It lies within the ecological perspective and at the intersection of language education and translation studies, relying in Kramsch's symbolic competence $(2006,2009,2010)$, and Tymoczko's holistic cultural translation (2007). Laviosa's intention is to 'open a dialogue between language and translation educators about the role of translation' by taking an 'ecological perspective on language education' (2), while seeking to contribute to organising and making more systematic the terminology used in this field.

Other researchers have subsequently dealt with various theoretical and terminological hurdles and have investigated particular phenomena. For example, González Davies has explored extensively the multiple use of translation and FL teaching by looking into bilingual dialogues and code-switching (2004); the role played by translation in other learning contexts (TOLC) in additional language learning (ALL) (2014); with Corcoll López she explored plurilingual practices and translation (2015); and plurilingualism in the monolingual class (2018). By invoking these contemporary practices and constructs, she unmistakably signals that future progress will depend on the extent to which theoretical reflection and empirical work incorporates contemporary thinking about multilingual language use, including translation, and is able to arrive at some level of terminological consensus that allows discussion and ultimately expanded forms of classroom practice to move forward in a useful fashion.

It is to this project, a more careful laying out of the terminological map used to describe translation in FL teaching, that the remainder of this section now turns. Discussion will consider current use and misuse of terms, in order to uncover potential negative effects, but with the goal of presenting a more comprehensive picture and proposing more appropriate approaches to pedagogical translation for contemporary classrooms.

Apart from these contributions, other prominent researchers-many of them working in European contexts - taking a closer look at translation and FL teaching and learning include Butzkamm and Caldwell 2009; De Arriba García 1996; Deller and Rinvolucri 2002; Duff 1989; Kerr 2014; Levine 2011; Malmkjaer 1998. Each contribution, whether based on theoretical or pragmatic grounds or adopting both perspectives, provides slightly different foci for the complex phenomena connected to translation in the FL classroom.

Generally speaking, it would be naive to think that a neat division between terms can easily be achieved. Indeed, it is striking that neither Lavault nor G. Cook define translation in the FL classroom. While they challenge established terms in their state-of-the-art discussions, they claim that there is sufficient space for different types of translation in the FL classroom. There is surely little disagreement on that point. The more pertinent question, however, is which approach is likely to be more supportive of enabling language teachers to incorporate translation in their pedagogical practice in the most facilitative way-an approach that is more inclined to blurring distinctions or one that calls for critical reflection and careful reviewing of how terms regarding translation-like practices are being referred to. At a time when the use of translation in language classroom appears to be at a crossroads, in this article I have chosen the latter approach.

\section{Translation in FL teaching and learning: restructuring the boundaries}

A good starting point for clarifying the different types of translation in the language classroom is De Arriba García's proposal (1996). Based on both Lavault's (1985) and Hurtado Albir's conceptualisations (1987: 77), she proposes accepting translation in the language classroom under the label of 'pedagogical translation'. According to her, this label allows the inclusion of translation FL teaching as a skill, one that entails the rehabilitation of the L1 in the FL classroom. She distinguishes three quite different phenomena under 'pedagogical translation'. First, translation in the FL classroom may refer to translating texts where students work on reading and writing skills as well as comparing grammar structures and other aspects between the two different languages. By contrast, a second kind-what she refers to as 'interior translation'-involves the student in translating an utterance produced in the 
$\mathrm{FL}$ into his/her L1 in order to access its meaning. This phenomenon is particularly prominent in the early stages of learning a FL, where it may constitute a strategy that allows students to compensate for a lack of knowledge in the L2. Finally, a third type of translation-'explicative' or 'explanatory translation'-is typically used as a resource by the teacher, for example as a way of explaining certain words and/or grammar content, to identify and avoid false friends, to enable students to understand certain utterances straightaway, or to check whether they have understood specific explanations. In all three instances, there is clearly space for the L1 in its various forms in the FL classroom—which is symbiotic to restoring pedagogical translation in the FL classroom (1996: 277-278).

While De Arriba García's discussion adopts a particularly interesting position, my proposal departs from a different premise, however, that can be summarised as follows: (a) indeed, it is the set of translating skills, best developed around a variety of tasks, which best defines the label of 'pedagogical translation'; and (b) pedagogical translation might primarily involve written, but increasingly intermodal translation tasks (such as subtitling and dubbing) with their need to mediate and transfer meanings. At the same time there is also a place in the classroom for both interior and explicative translation as quite distinct categories, as is well acknowledged by scholars like Hurtado Albir (1999) and Lavault (1985) and affirmed in reports from institutions such as the Directorate-General for Translation in the EU (2013, especially 7-8). These will be discussed in subsequent sections, in conjunction with the recent affirmation of bilingualism ${ }^{2}$ in contemporary classrooms. I will conclude with a proposal for a taxonomy of those terms related to translation in FL pedagogy, one that is fully aware that there is a distinctive dividing line between pedagogical translation and other types of $L 1 / L 2$ use in the classroom where the latter represents linguistic strategies or cognitive processes rather than tasks. It is in this context that G. Cook's broad notion of 'translation in language teaching' (TILT) is particularly useful since it can serve as an umbrella term for all types of translation in the language classroom -and which I adopt as such in this work.

As we embark on this project of terminological clarification, the first statement to be made is this: As a global concept, translation for professional purposes and translation in FL teaching refer to very different realities, a fact that, as the previous discussion has indicated is well reflected in quite different directions of research. By the same token, translation in the FL classroom itself is by no means univocal but, rather, comprises various categories which this section will begin to explicate.

By way of a general characterisation, 'pedagogical translation' refers to a mediating skill that entails meaning transfer and operates alongside other language skills in the FL classroom. An example may be any task that, frequently, requires working with a text, although activities vary greatly, as can be seen in Laviosa (2014, particularly 107-140), Leonardi (2010: 85-118), Carreres et al's. (2017) wide range of translation tasks under the latest trends of translation in the language classroom, or González Davies (2004), who offers a rich array of communicative and interactive translating tasks developed to be included in the translation and in the FL classroom and which focus on critical matters, from degrees of fidelity to cultural references and filters, intended meanings and linguistic skills (see especially 45-224).

This construct, however, is distinctive to a quite different phenomenon known as 'code-switching' (or 'code-mixing', see Cook 2010: 44), widely understood as the 'systematic, alternating use of two or more languages in a single utterance or conversational exchange' (Levine 2011: 50). Code choices that occur in the FL classroom are part of (oral) discursive practices (I emphasize that these are oral practices as traditional research is based on speech data ${ }^{3}$; see Lin and Li 2012) of bilingual or multilingual users, be it the teacher or the students- whether the code-switching is purposely or accidental is beyond this discussion. Additional concepts emerge with the consideration of the L1 use in the classroom and shifts across language boundaries. Such is the case of 'sandwiching', a teaching technique that consists in inserting a translation in the L1 after a concept or expression that students might find hard in the L2 followed by the expression in the $L 2$ and that helps them to understand (that is L2 > L1 > L2) (Butzkamm and Caldwell 2009: 33-34; Kerr 2014: 21).

The understated distinction between pedagogical translation and other uses of translation in $\mathrm{FL}$ contexts, I suggest, demonstrates the necessity of looking closer at patterns of $L 1 / L 2$ use in language 
pedagogy more rigorously allowing for the reinsertion of translation in language pedagogy under the auspices of good teaching practice. Ongoing debates and considerations at this juncture include scholarly discussions ascribed to code-switching, like 'code-choice' (Levine 2011), the technique of 'sandwiching', 'own language use' (see particularly Butzkamm and Caldwell 2009; Kerr 2014) and 'translanguaging' (see Canagarajah 2011, García and Wei 2014; Källkvist 2013) which will be analysed more closely in subsequent sections.

\section{Exploring (the use of) terminology in theoretical and empirical fields}

Fortunately, by now the expansion and revision of translation and FL teaching involves an increasing number of scholars who acknowledge (and cherish) the importance of translation in language teaching and who have started to refer to, as well as develop, 'pedagogical translation', and begin to build a certain unity and coherence for this area: Pedagogical translation is now an emergent concept employed across different disciplines within the theoretical and empirical literature.

However, this has not always been the case. To an extent, it is natural that any activity that involves the use of dual or multiple codes in the foreign language classroom among the classroom members, such as code-switching, code-change, code-choice or other tasks ascribed to it, tends to be associated with translation and/or pedagogical translation. Indeed, these are often dealt with in close proximity to each other, especially in the FL pedagogy literature and in arguments for bilingual teaching and learning that are interwoven with arguments for translation in language teaching-as they are closely associated with interior ${ }^{4}$ and explicative translation.

Thus, the argument of this article is not based on the contentious nature of L1/L2 use or codeswitching and its (negative) effects, but rather on the need to define the construct of pedagogical translation as a valid category of translation in the FL classroom different to code-switching and other neighbouring concepts. As a matter of fact, Leonardi (2010) and Laviosa (2014) are the only scholars who provide a strong case for 'pedagogical translation' or 'pedagogic translation' ${ }^{5}$ respectively legitimating this as an additional instrument in FL teaching and learning. Most researchers argue the case for various forms of L1/L2 use in language pedagogy neglecting this specific form (see in particular Butzkamm and Caldwell 2009; Cook 2010; Deller and Rinvolucri 2002; Kerr 2014; Levine 2011), where authors refer to bilingualism, code-switching, own language use, translanguaging and translation in a general sense). While there is a case for various L1/L2 use(s) in FL teaching and learning these are valid upon different premises and purposes.

Hence, the inconsistent use of notions and pedagogic practices may result in harmful connotations of pedagogical translation and the subsequent recommendation that translation in language teaching should generally be forbidden. The traditionally widespread sense of mistrust or discomfort is partly due to a lack of terminological consistency in this field narrowing the possibility of developing pedagogical translation beyond a L1 use.

For that reason, the reassessment and restoration of translation has to take place through the reassessment and clarification (when needed) of terminology (Weissmann referring to translation as a mediating skill, 2012) in an attempt to guarantee the foundations of pedagogical translation and other concepts rooted in L1/L2 use. Modern approaches denote the use of more accurate concepts that reflect the latest theoretical and pedagogical trends in language education-as seen in works of Cook (2010), Hurtado Albir $(1988,1999)$ Laviosa $(2014)$ and Leonardi $(2010)$, who refer to rather inclusive concepts of translation in language pedagogy. Despite the developments, the widespread use (and spirit) of older concepts like 'theme', 'prose' or 'version', all closely associated with the widelydismissed grammar translation method, remain pervasive, particularly amongst scholars and teachers in Higher Education sectors. These contradictory parameters undermine the development of this field and clearly identify a critical stage for research and praxis of translation in the FL classroom suggesting that the progress remains fragile with the unfortunate consequence that institutions, teachers, and scholars are unable to put into practice an updated framework of TILT to the benefit of FL teaching and learning. 
The issue regarding 'version' (translation from L2 to L1) and 'theme' (translation from L1 to L2) was already criticised in 1985 by Lavault as processes of controlling grammatical knowledge especially (37-45). As previously discussed, Lavault was a pioneer in these matters and predicted the problematic of imprecise terminology and, by implication, imprecise conceptualisation of the issues. While accepting the clear dichotomy between pedagogical and professional translation as well as the role of different concepts of translation in language teaching, she acknowledged the difficulty of dealing with terminology depending on the various schools of thought (1985: 10-11). Lavault rejected quite pointedly that pedagogical translation be reduced to the categories of 'theme' and 'version' or to literal renderings which seek to be 'very faithful to words and original formulations (each word has to be translated) and the most elegant possible' (my translation).

The following two sections will explore the use of terminology in recent literature that addresses translation in the FL classroom. I will first examine the use of terminology in theoretical frameworks and consider whether it is consistently employed or not. I will then look at the approaches and use of terminology within empirical studies that deal with translation in language teaching. The exploration of these sections intends to examine both sides of the debate, that is, theory and empirical studies, explaining whether there is a pattern in the use of terminology of translation and envisaging how this may affect the development of pedagogical translation.

\section{Terminology used in theoretical frameworks}

The reassessment of translation in language teaching can only be understood through the kaleidoscope of the different models, theories and approaches to discourse, pragmatics and literature in second language acquisition, translation studies and linguistics. Despite early attempts to present translation in language teaching as a positive and dynamic element, dissent on this and a focus on the grammar-translation method resulted in the neglect and even outright rejection of pedagogical translation. Some scholars simply do not use this (relatively new) label, as examined later in the article, preferring other labels for essentially the same practice; other are reluctant to deploy this label without caution (Carreres et al. 2017: 101-102); pedagogical translation may be identified with erroneous terms, resulting in misconstructions of the concept; scholars from research areas that have little familiarity with issues in language pedagogy may not identify the concept at all. Finally, scholars that have traditionally rejected a connection between second and foreign language acquisition and translation may prefer to remain outside the field of pedagogical translation as doing so may challenge their own disciplinary identity and undermine their own professional credibility.

The following discussion of the evolution of concepts associated with TILT illustrates these diverse dilemmas. Translation in language teaching according to various trends over the last two or three decades has been referred to as 'traduction didactique' (or 'didactic translation', see Weiss 2013), 'traduction universitaire' or 'traduction académique' (Delisle and Lee-Jahnke 1998: ix-x), 'traduction scolaire' (Grellet 1991: 86; Lavault 1991: 54) or 'traduction pédagogique' (Lavault 1985) —also known as 'pedagogical translation' (Hurtado Albir 1999; Leonardi 2010); 'pedagogic translation' (Laviosa 2014); or 'educational translation' (Laviosa, personal correspondence, 2018). The use of different terms in multiple languages that account for the same concept (as a result of different research traditions) blur the boundaries and hinder the development of pedagogical translation. Exploring whether the meaning of multiple terms in this field corresponds to the same concept (and praxis) is in order so that boundaries between them can be negotiated.

Translation in language teaching or TILT has been traditionally juxtaposed to 'professional translation', a terminological contrast that has not worked completely. In fact, in the case of translation in language teaching it appears to offer a limited perspective and has been challenged by scholars like Pergnier, whose prologue to Delisle and Lee-Jahnke's volume on language and translation teaching claims that 'traduction didactique' versus 'traduction professionnelle' should no longer be regarded as two opposite ends but as part of a continuum in a manner that will allow these practices to make significant advances in the pedagogical research of each field (1998: ix-x). The same insight is shared 
by Carreres (2014) and Carreres et al. (2017) who advocate for a continuum that associates translation as a means and translation as an end.

However, this does not seem to favour the use of 'pedagogical translation'. This term is seldom used by scholars, especially by those whose research involve translation in the FL classroom and long established disciplines-such as literature in the case of Soler and Wheeler (2015), subtitling in the case of Díaz Cintas (2008) and Ghia (2012), as well as institutional reports from the European Commission (2011) assessing the value of translation in the language classroom, the Modern Language Association (MLA) on Foreign Languages and Higher Education (2007) or recent reports from the Council of Europe's Language Policy Unit (2014-2016) providing a descriptive scheme for mediation (as the fourth mode of language activity according to the Common European Framework of Reference for Languages or CEFR (2001). The limited use of this term is probably due to the fact that it is not a widely-known concept outside language pedagogy or because it is not considered to provide enough reliability as an interdisciplinary concept: If we think about it, the development of interdisciplinary areas often entails a certain degree of suspicion and scepticism in the fields involved, and this in turn affect terminology. Soler and Wheeler (2015: 2), for instance, maintain that 'educational theory surrounding the teaching of foreign languages has felt the need to relinquish translation as a means of establishing its own independence'. By the same token, translation studies have been blamed for mistrusting other disciplines, so this is not a one-way issue:

There must be power(ful) reasons behind the call to restrict, rather than welcome, the expansion of research orientations in translation studies in the dubious belief that other disciplines might be willing to include in their priorities research related to translation which has, nevertheless, been discarded from our field. Otherwise it is difficult to understand why translation studies seem to be committing the same error of which it was once the victim: precisely the institutional underestimation of certain types of research was one of the problems which threatened and in fact curtailed to a considerable extent the emergence of studies now considered to be central to our field. (Martín Ruano 2006: 46)

There are additional challenges to the concepts of TILT and pedagogical translation with the development of conceptualisations based on new realities like that of multi- and plurilingualism that acknowledge that today's language classroom is open to multilingual learners with diverse language backgrounds different to L1 versus FL/L2. Moreover, language competence is increasingly discussed within the scope of 'multicompetency' 'that functions symbiotically for the different languages in one's repertoire' (Canagarajah 2011: 2) suggesting a need to revisit the new spectrum in which L1/ L2 use and translation are superseded by other concepts that represent new phenomena more precisely. A glance at the latest approaches to 'monolingualism','bilingualism', 'plurilingualism', 'multilingualism', and 'mediation', all which can be associated to translation in the language classroom question the prevailing static picture of this practice, thereby providing another justification for revision.

Just how complex that turns out to be can be seen from the fact that the association/dissociation of these terms is a relatively new phenomenon. The most recent is a report from the Council of Europe Unit, which has expanded the notion of 'linguistic mediation' originally covered in the CEFR (where translation and related tasks are acknowledged) and reconsiders a richer concept under a variety of angles: Mediation is no longer only regarded at linguistic but also at cultural, social and pedagogic levels. A recategorization and advanced description of mediation shows the calibre and the necessity to explore this conceptualisation further.

The Directorate-General for Translation in the EU's report published in 2013 reassesses translation in multilingual classrooms looking at the role of translation in language learning based on the principles that an 'active promotion of a Europe that is multilingual and multicultural largely requires that individual citizens be plurilingual or polyglot' (1). In North America, the Modern Language Association (MLA) Ad hoc Committee on Modern Languages' report of 2007 examines the current language teaching prospect in Higher Education recommending a series of changes in academic programmes in line with an integrative approach, as well as working towards translingual and transcultural competences. The nature of the reports issued by the MLA and the Directorate-General for Translation in 
the EU is clearly different, and it is also noticeable that the MLA does not put an emphasis on issues discussed in Europe (and in this article) like that of monolingualism vs bilingualism or multilingualism and translation in language teaching -with which the Directorate-General for Translation fully engages. The report issued by the Directorate-General for Translation (2013) discusses the meaning and the nature of translation in this context and puts forward various ways of using translation: It may be used by the teacher in order to help the student understand something, (also referred to as 'scaffolding translation'(7), it may be used at the initial stages of language learning by the FL student (also known as 'mental translating', 14) or as an activity that promotes language learning (the Directorate-General for Translation suggests a number of mediating activities to work with 'pedagogical translation' in an effective manner in the final part of the report, 125-133). Readers are likely to have noted that these descriptors largely align with the subcategories of 'pedagogical', 'explicative' and 'interior translation' as different types of translation in the FL classroom that I suggest working from De Arriba García's (1996) model.

The debate on 'scaffolding' and 'mental translation' reactivates the reassessment of code-switching as a process closely associated with translation:

\footnotetext{
A key argument in debates about translation is the extent to which it constitutes an activity that is in some way inevitable or even natural. Here, the major false premise is that L1 and L2 are presumed to be separated in the process of learning, either socially or cognitively. A more specific version of this question is the proposition that learners of L2 cannot help but engage in translation between L1 and L2 in the learning process. In the second decade of the twentieth century, this tended to be reformulated as a question of whether 'code-switching' (...) should be used in the classroom, and whether students should be allowed to do so. (DGT 2013: 22)
}

'Scaffolding' or 'explicative translation', on the other hand, is connected to other conceptual entities such as that of 'languaging'. For example, in her discussion of 'languaging' (understood as 'the use of language to discuss various aspects of language use') and translation in the FL classroom, Källkvist (2013) considers the positive effects of the use of different codes in the classroom. Further extension of this construct occurs with 'translanguaging', a process used 'for describing code-switching in multilingual individuals' (Källkvist's 2013: 218) or 'the ability of multilingual speakers to shuttle between languages treating the diverse languages that form their repertoire as an integrated system' (Canagarajah 2011: 401) and is therefore particularly suitable for describing the reality of multilingualism in contemporary classrooms. Translanguaging 'includes code-switching and translation, but is not limited to these' according to García and Sylvan (2011, in Gallagher and Colohan 2014: 3). Canagarajah (2011) underlines the growing interest in this phenomenon, and identifies a number of different labels documenting translanguaging with origin in different fields, such as codemeshing, code-switching, translingual writing, multiliteracies, and plurilingualism but does not distinguish necessarily these terms as he sees them as part of the translingual practice (that is, translanguage becomes an umbrella for all these dynamic terms surrounding the language practices in multilingual encounters). Canagarajah's approach is comprehensive and adopts an exhaustive focus that comprises linguistics, cognitive competence, and important social dimension. Many of these dimensions are essential to the scope of translation in the language classroom interrelating with other phenomena that arise in the FL classroom. In the same vein, conceptualisations such as 'explicative translation' (or 'scaffolding'), 'interior' (or 'mental') translation, 'languaging', 'translanguaging', 'multilingualism' and 'plurilingualism' are all processes that relate to using multiple languages in the classroom and which add new dimensions to translation in the language classroom and to bilingual education. The connection and the boundaries between these phenomena in relation to TILT and pedagogical translation need to gain visibility in order to understand the possibilities for their success in language pedagogy.

While García and Wei's (2014) principles of translanguaging and the engagement in the social construction of language goes beyond our scope, these authors bring to the fore an essential aspect ascribed to translanguaging: the phenomenon of translanguaging to teach and to learn. For Becker (1995) learning a FL implies learning 'a new way of being in the world' (see García and Wei 
2014: 227). In order to learn, learners must develop 'a sense of self' that will allow them to engage in the learning process and to participate in the act of languaging and meaning making (79). The learner's engagement become particularly important, as '[i]t is through meaningful participation in the act of learning enabled by translanguaging that bilingual students can create for themselves identities that are also academic (Palmer 2008), and thus invest in learning' (79-80).

Languaging, translanguaging and L1/L2 use is of utmost importance as a way of accepting and underlining the agency of language users who take part in interactive meaning making (9), closely related to the CEFR notion of mediation $(2001,2018)$. If 'languaging' refers to 'language as an integral and natural component in interaction, communication and construction of meaning' in Shohamy's (2006: 2) words, 'translanguaging' allows the bilingual learners to 'take control of their own learning, to self-regulate when and how to language, depending on the context in which they are being asked to perform' (80). Self-regulated learning, or what Williams (2012) refers to as 'natural translanguaging' (that is, the use of languaging by students in pairs or small groups in writing or oral activities to make sense of the content) does not preclude from 'official translanguaging' (also Williams 2012), set up by the teacher (in García and Wei 2014: 81-91).

This complex network of theories and models challenges the concept of 'monolingualism', which traditionally excluded the L1 in the classroom, as Howatt claimed (1984). Specifically, while investigating the use of L1 in FL classrooms as a constructive practice, Cook (2001) called for lifting this exclusion: He defended code-switching, understood as a strategy and a link between L1 and L2, and concluded that languages cannot be compartmentalised. To him, code-switching between two languages reflects pervasive realities regarding 'speech function, rules of discourse, and syntactic properties of the sentence' (408).

Translation and code-switching have been associated and dissociated alternately. On occasions, both are identified under the same rubric. However, code-switching may remain oblivious to translation (as seen in Turnbull and Arnett's study (2002), explained later in this article). This leads us to suspect that translation is wrongly described when mentioned in scholarly research within language education, and that translation is still perceived as a damaging element (Malakoff and Hakuta 1991, cited in Cook 2001: 417) when it is not referred to:

The word 'translation' has so far been avoided as much as possible because of its pejorative overtones in teaching. Translation as a teaching technique is a different matter from translation as a goal of language teaching. (...) Like code-switching, translation is a unique attribute of L2 users and a normal part of many of their lives.

This perception is so common that it is still captured in recent works such as that of Kelly and Bruen (2014):

It should be highlighted that the lecturer avoided the use of the word 'translate' or 'translation' when using TILT, favouring instead expressions such as 'If this book was published in English, what would it be called' or 'what would be a suitable slogan for this advertisement if it were to appear in an Irish newspaper'. By avoiding the word 'translate', the lecturer felt that students went beyond rewriting the L2 task in the L1, and approached it from an angle that considered L1 register, style and expression. (15)

Despite the (erroneous) identification of translation (used as a general term) and code-switching, there is an increasing acceptance of translation as specific practices in language teaching overall. This change is favoured largely by the multilingual turn in language pedagogy and by pluricultural societies.

The CEFR (2001) has been instrumental in acknowledging the value of translation in language pedagogy as it promotes 'plurilingualism in response to European linguistic and cultural diversity' (8) and reclaims the relevance of $\mathrm{L} 1$, translation and interpreting as mediating activities in which the language student becomes a mediator between different languages and cultures (Gutiérrez Eugenio 2013: 444). Linguistic mediation, 'appears (. . .) as a means by which translation could acquire a new legitimacy while complying with the requirements and objectives of modern teaching' and enables the restoration of activities that involve translation' (Weissmann 2012: 316). While mediation provides a concept that is akin to TILT it extends its reach by incorporating negotiating principles. 
The array of terms discussed in this section gives evidence of the extended presence of translation in the classroom and the growing support to include translation in language teaching in light of new dimensions. It also underlines the necessity to work towards an accurate terminological framework that will help develop an unambiguous area of pedagogical translation within the different uses of L1/L2 in the language classroom.

\section{Terminology used in empirical frameworks}

Along with this preoccupation with theoretical and pedagogical reasons for reconsidering the role of translation in FL teaching came a gradual increase in empirical studies. An early example is the study by Duff and Polio (1990) which revealed the overall satisfaction of university students with the teacher's use of L1 irrespective of the greater or lesser use. More recent investigations that echo the considerable interest of late in motivation and attitudes toward language learning is that of Kelly and Bruen (2014) who used translation studies as a way to investigate attitudes and behaviours in FL classrooms. The need to systematise the definitions and the terminology of translation and L1/L2 use in $\mathrm{FL}$ teaching within the theoretical prospect is even greater in empirical studies as interests are multiple and the terms deployed may not be necessarily at the centre of the discussion.

In the last few years, European institutions have explored this issue publishing a number of formal reports and revealing a growing interest in phenomena relating to language use and FL teaching. The Directorate-General for Translation in the EU, who ultimately aimed at identifying whether translation in the language classroom is effective or whether it represents a hindrance (2013:3) analysed the role of translation in language learning in various studies: Key Data on Teaching Languages at School in Europe (2005, 2008, 2012), Europeans and their Languages (2006, 2012), First European Survey on Language Competences: Final Report (2011). The DGT's 2013 report states that none of these studies explicitly mention translation in relation to language teaching, learning or testing which reveals how isolated this area remains, at least conceptually, and that there is a clear gap between colliding theory and practice:

None of the documents on multilingualism actually relate translation to language teaching in any clear way. Translation is certainly mentioned, but always in sections that remain quite separate from the comments on improving language teaching. Language learners learn languages; professional translators translate; and those are seen as quite separate worlds. (2)

Surprisingly however, studies exploring translation in the language classroom have multiplied in the last decade within a variety of disciplines and a focus on multimodal areas. While some coincide with the issues presented in the theoretical framework in the previous section of this article, others introduce refreshing areas in research.

The following classification explores the different nature of some of the latest empirical research on translation or L1/L2 use in the language classroom relevant to this article. The studies included in this taxonomy indicate that translation is perceived as a beneficial practice in learning a foreign language overall. They illustrate a wide range of research lines that explore translation in language teaching and learning but also how differently authors deploy terminology. Ultimately, it reflects the manifold interests against the complex and evolving background of TILT. In the spirit of giving an inclusive and neat insight, I have categorised empirical studies around: (a) translation, language use and code-switching; (b) translation as a pedagogical tool; (c) translation and written skills; (d) translation as a technique that reinforces language control; (e) translation in multimodal disciplines. Only Sánchez Cuadrado (2011) focuses explicitly on pedagogical translation. Other studies refer to code-switching, TILT, translation as a language skill, translation as a language strategy or translation as a multimodal tool. All seem to perceive translation as a valuable pedagogical resource in FL teaching and learning under various conceptual frameworks and targeting different skills and cognitive processes. However, just as with divergent theoretical framework, empirical studies do not offer a unified approach to the concept of translation in the language classroom or what this entails. 
Most research evolves around language use, code-switching and translation-probably because there is a natural connection among these terms. Translation as a pedagogical tool, translation as a technique, or the association between translation and written skills seem to be much less researched.

Translation, language use and code-switching: Turnbull engaged in a number of studies: in 2000 he analysed the use of language (English as L1 and French as L2) by four teachers of French in secondary schools; on another study, Turnbull (2001) investigated the experiences of training teachers before and after the beginning of the course, as well as the opinions and attitudes of students about using the L1 and L2 in the FL classroom before they started the classes; and in 2001 Turnbull and Lamoureux looked at students' perspectives on how language is used in the classroom. In a later work Turnbull and Arnett's (2002) literature review focused on the use of the target language (TL) and the L1 in L2 or FL teaching contexts urging that further research be taken primarily in relation to the use of patterns and attitudes of teachers and students. The extensive review includes relatively early empirical research on the teachers' L1/L2/FL use in the classroom, how much, when and why the L1 or L2 are used, and the beliefs of students and teachers around using one language or another. Empirical studies on language use include those of Castellotti (1997), who looked at the principles of conscious change of code from Spanish to English in the classroom; Gearon (1997), who examined teachers' change of intra and intersentential codes in relation to the dominant language (English, the L1) against the L2; and Macaro (1997), who explored the use of $L 1$ and $L 2$ in training/beginner/experienced teachers in secondary schools in England and Wales. The impact of students' perspective on language use is explored in Duff and Polio (1990) and Macaro's (1997) studies. The review concludes that there is a need to optimise the use of the L1 in the FL class, that is, to maximise the use of the TL to the student and to use the student's L1 'judiciously' (205). Future research will need to determine what this actually means in terms of L1 and L2 use quantity or quality and to analyse whether it is acceptable and effective for teachers to use the students' L1. While the review discusses language use, code-switching and classroom discourse, it does not mention translation.

Edstrom's (2006) research on the use of L1 in the L2 classroom identifies code-switching and translation as a general rule as he refers to ' $\mathrm{L} 1$ use' in most of the article, but uses 'translation' in some cases. The author distinguishes different categories of translation exploring them in the context of (unsuccessful) vocabulary activities, grammar-related questions, cultural issues; and connecting with students and translation.

However, contributions that study code-switching without focusing on or mentioning translation as part of their framework include Majer (2009), who examines intra-sentential code-switching (which he identifies with 'code-mixing') patterns in the FL classroom and Liebscher and Dailey-O'Cain (2005) who explore code-switching in an advanced FL classroom.

Advances in the terminology deployed and the frameworks used can be seen in a more recent study by Corcoll López and González Davies (2015). The authors consider the impact of informed code-switching in the plurilingual classroom and explore the benefit(s) of implementing code-switching and translation as two plurilingual learning strategies following two different constructs: pedagogically-based code-switching (PBCS, related to code-switching, as 'the ability of plurilingual speakers to within or between sentences from and to the codes in their repertoire') and translation in other learning contexts (TOLC, related to translation, as it is intended to acquire 'linguistic mediation skills in fields other than Translation Studies' 2016: 69), both framed within the framework of Canagarajah's definition of 'translanguaging' (see page 21 of this article) where students develop their plurilingual, pluricultural and communicative competences.

Translation as a pedagogical tool: Specific research on particular practices of translation in language education remains scarce. Although most scholars and practitioners focus on translation into the students' L1, Sánchez Cuadrado (2011) looks specifically at pedagogical translation into the FL exploring the students' experience under various categories that include processes, characteristics and skills. The study, which reflects on the complexity of translating into the FL, shows the beneficial impact of this practice in language learning. 
More recent studies led by Kelly and Bruen $(2014,2017)$ bring attention to translation in the language classroom as TILT and reveals that teachers perceive translation in language teaching as a positive pedagogical tool in the classroom.

Translation and written skills: In her study Pariente Beltrán (2013) suggests the limited empirical research to evaluate a positive correlation between these elements. She identifies the impact of translation in the FL classroom looking at implicit versus explicit instruction and translation in an advanced Spanish grammar module at university level, and advocates the necessity to rethink the integration of translation in language teaching as 'consciousness-raising, attention and language awareness, taskinduced involvement load and genre-based L2 writing instruction' (11).

Translation as a technique that reinforces language control: Whyatt (2009) tests language control (understood as 'an alternative means for understanding both the development and the breakdown of performance in L2' [Gollan and Kroll 2001, in Whyatt 2009: 184]) and error patterns in translated texts to prove that translation tasks improve language control in the mind of a $L 2$ learner and demonstrates that since language control is an issue among $L 2$ learners an awareness of language control is needed. The practice of translation in L2 teaching reveals itself as beneficial in students' learning process as 'it engages their full cognitive potential, puts their bilingual knowledge to the test, raises their interlingual and intercultural awareness and helps [the students] to organise the two linguistic systems (...). It raises students' motivation to learn more, helps them to gain more linguistic self-confidence and eventually may lead to better language control' (199-200).

Translation in multimodal disciplines: In this expanding field, Incalcaterra McLoughlin (2009) explores code-switching and subtitling (as a modality of translation) in language learning and discusses how subtitling enhances 'a selective and critical use of translation' (236), which in turn may have positive effects on the learner.

One thing is clear: There is a true interest in translation and L1/L2 use in FL language. Simultaneously, the lack of unison in the application of terms reflect a complex relationship between disciplines and their conceptual frameworks. The negative consequences are well documented in the Directorate-General for Translation's report, which undertakes a large qualitative empirical study that examines how translation and language teaching relate to each other. The study focuses primarily on the effectiveness, methodology, curricula, and attitude to translation in language teaching among experts on translation (57 respondents) and teachers (896 respondents), as well as two focus-group sessions (one in Tarragona and one in Leicester). Data from the experts' and teachers' questionnaires were discussed with stakeholders and yield the following results: (a) Only two respondents are not in favour of using translation activities in the language learning classroom; ${ }^{6}$ (b) the Tarragona group identified a need to distinguish between 'translation' and 'code-switching' as for some, the exclusion of $L 1$ in the FL classroom necessarily entails leaving out translation, while others dismiss L1 but include translation. This highlights the divide around the construct and the use of translation. In either case 'translation' in the classroom context was understood both in written and spoken forms (DGT 2013: 36).

A general conclusion is this: The more translation is interpreted as involving communication and intercultural competence, the more favourable the attitude toward it among both researchers and teachers and the less conceptually opposed it is to language learning. In other words, at heart, terminological issues drive whether and how the use of translation in the FL classroom is valued. Interestingly, the Directorate-General for Translation draws attention to the terminological problems of translation in language teaching. Furthermore and quite curiously, even though the grammar translation method has been highly criticised and theoretically ostracised within the profession for a considerable time period, current lines of research are still influenced by this negativity, a factor that hinders further progress in this domain of research and practice.

\section{Proposal for a revision}

This contribution does not intend to get into the technicalities of terminology. Rather, it explores and reflects on how the (mis)use of terminology can challenge further the acceptance and good practice 
of translation in language teaching. While it is true that translation in language pedagogy lies within areas of contact, it is also true that this field will benefit from a clearer classification of the network of terminological uses across disciplines in an explicit way.

It is not easy to explain terminology beyond the obvious descriptions, as it is essential to take into account a specific discussion matter (for instance, one may focus on different cognitive exercises that trigger reflecting on interior translation, while another subject may be focusing on written exercises of pedagogical translation) and the tradition(s) followed in each subject. However, developing alternative ways of conceptualising the boundaries of translation in language education could yield important insights into the debate.

The implementation of a new framework relevant to current research in translation in language teaching is long overdue (Campos Plaza and Ortega Arjonilla 2005: 179). For this reason, I suggest reassessing the borders of translation in the language classroom based on the following map. The map aims at acting as a starting point of discussion on different types of translation and L1/L2 use in language teaching. The terms discussed throughout the article have been organised and are described in order to show how this network of neighbouring concepts around translation best works depending on their role and its use(s). The concept of 'mediation' is not included explicitly in my approach, for purposes of clarity, even though it is in line with the inclusive term of TILT. Initially presented under a linguistic angle in the CERF (2001), a revised concept refers not only to those activities or strategies that involve the use of two or more languages and where negotiating principles are necessary, but it is currently regarded as a comprehensive term that includes linguistic, cultural, social, and pedagogic aspects. Mediation emphasises the co-construction of meaning and interaction and relates to the social and individual dimensions in FL learning (see the CEFR Volume Companion, 2018; Pintado Gutiérrez forthcoming) and is inclusive of all language activities providing that they enable communication when constraints make it difficult (Carreres et al. 2017: 100).

TILT is therefore presented as an umbrella under which various forms of L1/L2 uses and processes are classified and explained accordingly. In the self-explanatory map I present 'translation in language teaching and learning' is an all-embracing term that comprises the inclusion of translation in the language classroom according to the different terms and their nature (pedagogical translation, or translating tasks; code-switching, or interaction in the classroom; and interior translation, or cognitive strategy). This map is based on the discussion of this article and aims to provide an integrating view of the latest trends, debates and dialogues in the spirit of making further progress in this field (Table 1).

This map is conceived to serve as a basis for future research and discussion on translation in language pedagogy. The taxonomy does not prioritise the establishment of an exhaustive terminological correlation but it clearly indicates the problematic with terminology analysed and discussed throughout the article opening a dialogue that allows for an informed permeability among pedagogic practices rather than suggesting a constrained construct. While terminology is not restricted to the taxonomy previously suggested, and categories may overlap, it also evidences the integrative nature of TILT and it highlights the singularity of pedagogical translation as a category of translation in language pedagogy with an intrinsic value in itself.

The scholarly work around translation in language teaching through various interdisciplinary foci reveals translation and the use of L1/L2 in the classroom as a holistic concept that comprises complex processes which activate different purposes and mechanisms. A systematic use of translation in language pedagogy and its subcategories will aid the development and good use of pedagogical translation in the language curriculum consistent with a well-founded pathway -initial discussions may be based on the map presented earlier. A gradual use of standard terminology in this area will redefine translation in the language classroom according to newly revealed facets and in line with the latest trends in the field and an appropriate practice.

The plurilingual communicative competence (PCC) that González Davies (2018) advocates is very much in line with this proposal. The PCC, defined 'as an appropriate use of natural plurilingual practices (e.g. translation, code-switching or an informed use of the L1) to advance inter-linguistic and inter-cultural communication' (125), is largely reflected in the map presented. In line with this, it is 
TRANSLATION IN LANGUAGE TEACHING AND LEARNING

The expansion of the original TILT term borrowed from Guy Cook (2010) entails an all-inclusive approach to the use of translation and L1/L2/ALL in language pedagogy where the various forms of the learner's own language use are perceived as part of the language teaching tools and mechanisms as well as learning processes. This term acts as an essential umbrella that includes different types of language use in the FL classroom, including translating per se, translation in relation to linguistic skills, translation and language alternation, and also translation as a cognitive strategy.

$\begin{array}{ll}\text { Term } & \text { Pedagogical translation } \\ & \text { *Also known as: } \\ & \text { pedagogic translation, didactic translation, traduction } \\ & \text { didactique, educational translation, traduction scholaire }\end{array}$

Nature

Translating tasks

Explanation Pedagogical translation designates those translating activities and/or tasks that are included in foreign language $(\mathrm{FL})$ teaching and learning. These tasks enhance the development of specific language and translating skills and are based on various aspects of translation and other pragmatic issues central to the FL classroom: language awareness, accuracy, pragmatic and intercultural competence, creativity, problem solving, and autonomy and collaboration, to name just a few. These translation based activities help the language learner to have a better command of the language and translation as a key skill for language users. It involves not only written activities but also multimodal material, including texts that reproduce oral features.

$$
\text { Code-switching }
$$

Interior translation

Classroom Interaction

Code-switching involves different forms of alternation between the learners and the teachers' languages ( $L 1, L 2$, interconnected nature of the concepts and the processes they represent. $^{7}$ exercises; languaging; translanguaging etc). That is, it refers to the interaction between the teacher and the students or among the students. Usually employed in an oral context, it applies to various situations, be it addressing problematic sources such a lack of understanding (for instance, clarifying linguistic or socio-cultural matters that the students find difficult to interpret), discussing certain communicative nuances by raising the student's awareness, maintaining the student's attention with the introduction of humour, etc. Terms relating to $L 1 / L 2$ use may overlap demonstrating the

Cognitive strategy

Cognitive strategies that involve the use of the students' own language (L1) or additional languages (ALL) as a tool. The student relies in his/her L1/ALL with the purpose of building, developing or structuring the knowledge of the foreign language (FL). This strategy usually happens instinctively and the learners are often unaware of it. Most research attribute this process to the earliest stages of learning a FL. languaging; translanguaging interior translation; mental translation; languaging; translanguaging 
essential to remember that theoretical discussion and praxis should no longer engage with double or multi monolingualisms but rather with more dynamic phenomena that capture the complexity of language(s) use-also true in the reconceptualization of pedagogical translation. While acknowledging that continuums proclaimed by key researchers such as Cook is key, a reflection on reconceptualisations is in order that will reveal diverse practices of translation and their potential.

Before concluding this section it is worth mentioning that this proposal faces a twofold issue: Even though terminology evolves, new or revised terms are not always embraced by scholars or educators; at the same time, there is a need to acknowledge the big challenges involved in legislating terminology.

\section{Conclusions}

A dialogue between fields remains valuable and even though the nature of the rapport between translation and language learning is different in the professional (translation) field and in the (foreign language) educational practice, their relationship is indissoluble. That is why we need to optimise this relationship rather than neglect the importance of this union. It is significant that pedagogical translation, of an interdisciplinary nature, may still be ignored by the areas that are closest to it. These conclusions highlight the need for a deeper analysis of the subject matter and of the boundaries considered within. My remapping of the conceptual landscape is intended to encourage further review of the research and the teaching practice of translation in language pedagogy. While G. Cook's approach to TILT in 2010 is still being discussed extensively by language educators and other scholars, new concepts such as 'translation in other learning contexts' (or TOLC, see González Davies 2014: 8-9) have emerged. Developments under the umbrella of complex correlations between linguistics and psycholinguistics, translation studies, and anthropology, to mention just a few fields, make a convincing case for further interdisciplinary collaboration, creating a real synergy among them.

This greater interdisciplinarity is an opportunity that we cannot afford to miss: It will open possibilities of reconceptualisation and it will allow to overcome challenges both in theory and in practice. The dynamic approaches to language in additional language learning (see May 2014) are central in exploring the construct of translation in the FL classroom and its impact in the pedagogical praxis, for instance in relation to the student/teacher agency and types of tasks developed. In other words, I suggest that it is necessary to capture the change in the landscape of translation within the classroom and beyond. The monolingual bias, as Ortega (2013) maintains 'has become unsustainable for the field of SLA, as for any other field that aspires to understand multiple-language learning as an object of inquiry and to support bi/multi lingualism as a societal and individual right and asset' (33).

The discussion of the various forms of translation in FL pedagogy has started to take hold as a major topic in areas related to applied linguistics research giving way to a substantial revision of what 'translation' means in research and among teachers: Whether a tool in language learning; as scaffolding in initial L2 learning; as a complex multi-skill communicative activity; etc. The more $\varnothing$ operative the concept (involving communication, intercultural competence) the more constructive the approach to translation. One major point of concern is thus the meaning and the applications of the term 'translation' and 'pedagogical translation' in the various practices that take place in FL pedagogy. I anticipate that an adequate taxonomy will bring agency to translation in the educational field as a foremost versatile teaching and learning resource.

\section{Notes}

1. In this article 'foreign language' is the general term chosen to discuss issues related to teaching and learning a non-mother language in the classroom. 'Second language' is retained when used by a specific author or in an empirical study.

2. The term bilingual learner is widely used in England as a broad category to refer to pupils who are at various stages of learning English as a second or additional language for studying purposes and who have at least 
some knowledge and who have some knowledge and skills in another language or languages already (see Leung, Harris and Rampton 2011: 44).

3. Even though there are specific translation oral tasks that may be classified under PT.

4. A phenomenon that should not be perceived as isolated, as it can be related, for instance, with other phenomena in translation studies through concepts such as bi-texts, a term coined by Harris (1988), and which refers to 'the mental status in the cognitive processes in the translators' (DGT 2013: 7).

5. Equivalent also to 'educational translation' and 'didactic translation' (Laviosa, personal correspondence, 2018)

6. Even though this data seems highly biased

in favour of the use of translation, and we have thus generally not used it in any quantitative way. The suspicion of bias comes from the way in which some well-known experts in language acquisition either dismissed the question of translation out of hand, or indicated their uneasiness or lack of qualifications to answer the questions. (2013: 32)

7. Debates on how these terms (code-switching, code-changing, code-mesging, languaging, translanguaging) relate can be seen in García (2009), who claims that translanguaging 'goes beyond what has been termed code-switching [...] although it includes it, as well as other kinds of bilingual use and bilingual contact' (45).

\section{Disclosure statement}

No potential conflict of interest was reported by the author.

\section{Funding}

This work was supported by the Faculty of Humanities and Social Sciences, Dublin City University: [grant number Spring Journal Publication Scheme 2017].

\section{References}

Baker, M. 2001. Routledge Encyclopedia of Translation Studies. London: Routledge.

Becker, A.L. 1995. Beyond Translation: Essay Towards a Modern Philosophy. Ann Arbor: University Michigan Press.

Butzkamm, W. and J. Caldwell. 2009. The Bilingual Reform: A Paradigm Shift in Foreign Language Teaching. Tübingen: Narr Studienbücher.

Campos Plaza, N. and E. Ortega Arjonilla. 2005. Panorama de lingüística y traductología [Linguistics and Translatology Landscape]. Granada: Atrio.

Canagarajah, S. 2011. Translanguaging in the classroom: emerging issues for research and pedagogy. Applied Linguistics Review 2: 1-28. doi:10.1515/9783110239331.1.

Carreres, Á. 2014. Translation as a means and as an end: reassessing the divide. The Interpreter and Translator Trainer 8: 123-35. doi:10.1080/1750399X.2014.908561.

Carreres, Á., M. Noriega-Sánchez and C. Calduch. 2017. Mundos en palabras. London: Routledge.

Castellotti, V. 1997. Langue étrangère et français en milieu scolaire: didactiser l'alternance? [Foreign language and French in school: the didactics of alternating?]. Études de Linguistique Appliquée 108: 401-10.

Colina, S. 2002. Second language acquisition, foreign language teaching and translation studies. The Translator 8: 1-24. doi:10.1080/13556509.2002.10799114.

Cook, V. 2001. Using the first language in the classroom. The Canadian Modern Language Review 57: 402-23. doi:10.3138/ cmlr.57.3.402.

Cook, G. 2010. Translation in Language Teaching. Oxford: Oxford University Press.

Corcoll López, C. and M. González Davies. 2015. Switching codes in the plurilingual classroom. ELT Journal 70, no. 1: 6777. doi:10.1093/elt/ccv056.

Cordero, A. 1984. The role of translation in second language acquisition. The French Review 57: 350-55. http://www.jstor. org/stable/392747.

Council of Europe. 2001. Common European Framework of Reference for Languages: Learning, Teaching, Assessment. Cambridge: Cambridge University Press. https://www.coe.int/t/dg4/linguistic/source/framework_en.pdf.

Council of Europe. 2018. Common European Framework of Reference for Languages: Companion Volume with New Descriptors. Cambridge: Cambridge University Press. https://rm.coe.int/cefr-companion-volume-with-newdescriptors-2018/1680787989.

De Arriba García, C. 1996. Uso de la traducción en clase de lenguas extranjeras: la traducción pedagógica [The Use of Translation in Foreign Language Class: Pedagogical Translation]. III Congrés Internacional sobre Traducció, UAB, 519-29. 
Delisle, J. 1980. L'analyse du discours comme méthode de traduction. Initiation à la traduction française de textes pragmatiques anglais. Théorie et pratique [Discourse Analysis as a Translation Method]. Ottawa: Presses de I'Université d'Ottawa.

Delisle, J. 1998. Fonctions de la Traduction en Didactique des Langues [The Role of Translation in Language Teaching]. Paris: Didier Erudition.

Delisle, J. and H. Lee-Jahnke. eds. 1998. Enseignement de la traduction et traduction dans l'enseignement [The Teaching of Translation and Translation in Teaching]. Ottawa: Presses de I'Université d'Ottawa.

Deller, S. and M. Rinvolucri. 2002. Using the Mother Tongue. London: English Teaching Professional/Delta.

Díaz Cintas, J. 2008. The Didactics of Audiovisual Translation. Amsterdam: John Benjamins.

Directorate General for Translation, European Commission. 2013. Translation and Language Learning: The Role of Translation in the Teaching of Languages in the European Union. Luxembourg: Publications Office in the European Union. https://publications.europa.eu/en/publication-detail/-/publication/aa06f9e5-5d27-4c8a-beb0-9abf9d91c179/ language-en.

Duff, A. 1989. Translation. Oxford: Oxford University Press.

Duff, P. and C.G. Polio. 1990. How much foreign language is there in the foreign language classroom? Modern Language Journal 74, no. 2: 154-66. doi:10.1111/j.1540-4781.1990.tb02561.x.

Edstrom, A. 2006. L1 Use in the L2 classroom: one teacher's self-evaluation. The Canadian Modern Language Review 63, no. 2: 275-92. doi:10.3138/cmlr.63.2.275.

Eurobarometer. 2006. Special Eurobarometer 386. Europeans and their Languages. http://ec.europa.eu/commfrontoffice/ publicopinion/archives/ebs/ebs_243_en.pdf.

Eurobarometer. 2012. Special Eurobarometer 386. Europeans and their Languages. http://ec.europa.eu/public_opinion/ archives/ebs/ebs_386_en.pdf.

European Commission. 2011. First European Survey on Language Competences: Final Report. http://ec.europa.eu/ languages/policy/strategic-framework/documents/language-survey-final-report_en.pdf.

Eurydice. 2005. Key Data on Teaching Languages at School in Europe - 2005 . European Commission (Directorate-General for Education and Culture). http://www.indire.it/lucabas/lkmw_file/eurydice///Key_data_languages_EN.pdf.

Eurydice. 2008. Key Data on Teaching Languages at School in Europe - 2008. Education, Audiovisual and Culture Executive Agency (EACEA P9Eurydice). https://ec.europa.eu/eurostat/documents/3217494/5718005/EC-81-08-375-EN.PDF/ 8954cd9a-39b2-4149-a36b-6acd87a3bfa5.

Eurydice. 2012. Key Data on Teaching Languages at School in Europe - 2012. Education, Audiovisual and Culture Executive Agency (EACEA P9Eurydice and Policy Support). http://eacea.ec.europa.eu/education/eurydice/documents/key_data_ series/143EN.pdf.

Gallagher, F. and G. Colohan. 2014. T(w)o and fro: using the L1 as a language teaching tool in the CLIL classroom. The Language Learning Journal. doi:10.1080/09571736.2014.947382.

García, O. 2009. Bilingual Education in the 21st Century. A Global Perspective. West Sussex: Wiley-Blackwell.

García, O. and L. Wei. 2014. Translanguaging. Language, Bilingualism and Education. New York: Palgrave MacMillan.

García, O. and C.E. Sylvan. 2011. Pedagogies and practices in multilingual classrooms: singularities in pluralities. The Modern Language Journal 95, no. 3: 385-400. doi:10.1111/j.1540-4781.2011.01208.x.

Gearon, M. 1997. L'alternance entre l'anglais et le français chez les professeurs de français langue étrangère en Australie [The alternation between English and French by teachers of French as a foreign language in Australia]. Études de linguistique appliquee 108: 464-74.

Ghia, E. 2012. Subtitling Matters: New Perspectives on Subtitling and Foreign Language Learning. New York: Peter Lang.

Gollan, T. and J.F. Kroll. 2001. Bilingual lexical access. In The Handbook of Cognitive Neuropsychology: What Deficits Reveal about the Human Mind, ed. B. Rapp, 321-45. Philadelphia, PA: Psychology Press.

González Davies, M. 2004. Multiple Voices in the Translation Classroom: Activities, Tasks and Projects. Amsterdam: John Benjamins.

González Davies, M. 2014. Towards a plurilingual development paradigm: from spontaneous to informed use of translation in additional language learning. The Interpreter and Translator Trainer 8: 8-31. doi:10.1080/1750399X.2014. 908555.

González Davies, M. 2018. The use of translation in an integrated plurilingual approach to language learning: teacher strategies and good practices. Journal of Spanish Language Teaching 4, no. 2: 124-35. doi:10.1080/23247797.2017. 1407168.

Grellet, F. 1991. Vers une Pédagogie Communicative de la Traduction [Towards a communicative teaching of translation]. Triangle 10: 85-93.

Gutiérrez Eugenio, E. 2013. La traducción y la interpretación como herramientas para fomentar el aprendizaje en el aula de ELE: Principios básicos y propuestas didácticas [Translation and Interpreting as Tools to Promote Learning in the Spanish as a Foreign Language Classroom: Basic Principles and Didactic Proposals]. In Actas del I Congreso Internacional de Didáctica de Español como Lengua Extranjera. Budapest: Instituto Cervantes. https://cvc.cervantes. es/ensenanza/biblioteca_ele/publicaciones_centros/PDF/budapest_2013/47_gutierrez.pdf.

Hall, G. and G. Cook. 2012. Own-language use in language teaching and learning: the state of the art. Language Teaching 45: 271-308. doi:10.1017/S0261444812000067. 
Harris, B. 1988. Bi-text, a new concept in translation theory. Language Monthly 54: 8-10.

Holmes, J. 1972. The name and nature of translation studies. In The Translation Studies Reader, ed. L. Venuti, $180-92$. London: Routledge.

Howatt, A.P.R. 1984. A History of English Language Teaching. New York: Oxford University Press.

Hurtado Albir, A. 1987. Hacia un enfoque comunicativo de la traducción [Towards a Communicative Approach to Translation]. Il Jornadas Internacionales de Didáctica del español como Lengua Extranjera: Ávila.

Hurtado Albir, A. 1988. La fidelidad al sentido: Problemas de definición [Loyalty to Meaning: Definition Issues]. In II encuentros complutenses en torno a la traducción, 57-64. Madrid: Instituto Universitario de Lenguas Modernas y Traductores, Universidad Complutense de Madrid.

Hurtado Albir, A. 1999. Enseñar a traducir [Teaching to Translate]. Madrid: Edelsa.

Incalcaterra McLoughlin, L. 2009. Inter-semiotic translation in foreign language learning. The case of subtitles. In Translation in Second Language Teaching and Learning, ed. A. Witte, T. Harden and A.R. de Oliveira Harden, 227-44. Frankfurt: Peter Lang.

Källkvist, M. 2013. Languaging in translation tasks used in a university setting: particular potential for student agency? Modern Language Journal 97: 217-38. http://www.jstor.org/stable/23361747.

Kelly, N. and J. Bruen. 2014. Translation as a pedagogical tool in the foreign language classroom: a qualitative study of attitudes and behaviours. Language Teaching Research 19: 150-68. doi:10.1177/1362168814541720.

Kelly, N. and J. Bruen. 2017. Using a shared L1 to reduce cognitive overload and anxiety levels in the L2 classroom. The Language Learning Journal 45, no. 3: 368-81.

Kerr, P. 2014. Translation and Own-Language Activities. Cambridge: Cambridge University Press.

Kramsch, C. 2006. From communicative competence to symbolic competence. The Modern Language Journal 90: $249-52$. doi:10.1111/j.1540-4781.2006.00395_3.x.

Kramsch, C. 2009. The Multilingual Subject: What Foreign Language Learners Say about their Experience and Why it Matters. Oxford: Oxford University Press.

Kramsch, C. 2010. Symbolic dimensions of the intercultural. Language Teaching 44, no. 1: 1-14. doi:10.1017/ S0261444810000431.

Lavault, E. 1985. Fonctions de la Traduction en Didactique des Langues [The Role of Translation in Language Teaching]. Paris: Didier Erudition.

Lavault, E. 1991. Traduire en classe. Pourquoi et pour Qui? [Translating in the Classroom. Why and by Whom?]. In The British Council. The Role of Translation in Foreign Language Teaching, 49-57. Paris: Didier Erudition.

Laviosa, S. 2014. Translation and Language Education: Pedagogic Approaches Explored. New York: Routledge/Taylor \& Francis.

Leonardi, V. 2010. The Role of Pedagogical Translation in Second Language Acquisition. From Theory to Practice. Frankfurt: Peter Lang.

Leung, C., R. Harris and B. Rampton. 2011. The idealised native speaker. Reified ethnicities and classroom realities. In The Routledge Applied Linguistics Reader, ed. L. Wei, 33-45. New York: Routledge/Taylor \& Francis.

Levine, G. 2011. Code Choice in the Language Classroom. Bristol: Multilingual Matters.

Liebscher, G. and J. Dailey-O'Cain. 2005. Learner code-switching in the content-based foreign language classroom. Modern Language Journal 89: 234-47. doi:10.1111/j.1540-4781.2005.00277.x.

Lin, A. and D. Li. 2012. Code-switching. In Handbook of Multilingualism, ed. M. Martin-Jones, A. Blackledge and A. Creese, 470-81. Abingdon: Routledge. doi:10.4324/9780203154427.

Macaro, E. 1997. Target Language, Collaborative Learning and Autonomy. Clevedon: Multilingual Matters.

Majer, J. 2009. A pedagogical evaluation of intra-sentential code-switching patterns in L2 classroom talk. Research in Language 7: 31-41. doi:10.2478/v10015-009-0003-8.

Malakoff, M. and K. Hakuta. 1991. Translation skill and metalinguistic awareness in bilinguals. In Language Processing in Bilingual Children, ed. E. Bialystok, 141-66. Cambridge: Cambridge University Press.

Malmkjaer, K. 1998. Translation in Language Teaching. Language Teaching in Translation. Manchester: St. Jerome.

Martín Ruano, M.R. 2006. Conciliation of disciplines and paradigms. In Translation Studies at the Interface of Disciplines, ed. J. Duarte Ferreira, A.R. Assis and T. Seruya, 43-53. Amsterdam: John Benjamins.

May, S. 2014. The Multilingual Turn. Implications for SLA, TESOL, and Bilingual Education. London: Routledge.

McLaughlin, B. 1987. Theories of Second Language Learning. London: Edward Arnold.

MLA Ad Hoc Committee on Foreign Languages. 2007. Foreign Languages and Higher Education: New Structures for a Changing World. https://apps.mla.org/pdf/forlang_news_pdf.pdf.

Mitchell, R. and F. Myles. 2004. Second Language Learning Theories. London: Edward Arnold.

Ortega, L. 2013. Moving beyond "Lingualism": multilingual embodiment and multimodality in SLA. In The Multilingual Turn. Implications for SLA, TESOL, and Bilingual Education, ed. S. May, 32-53. London: Routledge.

Palmer, D. 2008. Diversity up close: building alternative discourses in the dual immersion classroom. In Pathways to Multilingualism: Evolving Perspectives on Immersion Education, ed. T. Fortune and D. Tedick, 97-116. London: Multilingual Matters.

Pariente Beltrán, B. 2013. Evaluating translation as an explicit instruction tool to improve L2 written skills: an empirical study. PhD diss., University of Massachussets, Boston, MA. 
Pintado Gutiérrez, L. 2012. Fundamentos de la traducción pedagógica: traducción, pedagogía y comunicación [The fundamentals of pedagogical translation: translation, pedagogy and communication]. Sendebar 23: 321-53.

Pintado Gutiérrez, L. Forthcoming. Mapping translation in foreign language teaching: demystifying the construct. In Translating and Language Teaching. Continuing the Dialogue, ed. M. Koletnik and N. Froeliger. Newcastle upon Tyne: Cambridge Scholars Publishing.

Sánchez Cuadrado, A. 2011. Análisis de las Percepciones de Estudiantes de E/LE hacia Actividades de Traducción Pedagógica [Analysis of Spanish as a Foreign Language Students' Perceptions towards Pedagogical Translation Activities by]. Paper presented at Congreso Mundial de Profesores de Español, Instituto Cervantes. http://comprofes. es/posteres/análisis-de-las-percepciones-de-estudiantes-de-ele-hacia-actividades-de-traducción-pedagógi.

Shohamy, E. 2006. Language Policy: Hidden Agendas and New Approaches. London: Routledge.

Soler Pardo, B. and D. Wheeler. 2015. Translation and didactics in the language classroom: the preparation and dissemination of a dual-language critical edition of José Luis Alonso de Santos' Bajarse al moro/Going down to Morocco. The Interpreter and Translator Trainer 9: 30-49. doi:10.1080/1750399X.2015.1019734.

Stern, H.H. 1992. Issues and Options in Language Teaching. Oxford: Oxford University Press.

Turnbull, M. 2001. There is a role for the L1 in second and foreign language teaching, but ... . Canadian Modern Language Review 57, no. 4: 531-40.

Turnbull, M. and K. Arnett. 2002. Teachers' uses of the target and first languages in second and foreign language classrooms. Annual Review of Applied Linguistics 22: 204-18. doi:10.1017/S0267190502000119.

Turnbull, M. and S. Lamoureux. 2001. L1 and L2 use in core French: a focus on pre-service students' views and classroom practice. The annual conference of the Canadian Association of Applied Linguistics, Quebec, Canada.

Tymoczko, M. 2007. Enlarging Translation, Empowering Translators. Manchester: St. Jerome.

Wei, L. ed. 2011. The Routledge Applied Linguistics Reader. New York: Routledge//Taylor \& Francis.

Weiss, I.M. 2013. De la comprensión del texto a la constitución de una nueva realidad textual: sobre los límites de la transferencia cultural en la traducción didáctica [From Understanding the Text to Building a New Textual Reality: The Limits of Cultural Transfer in Pedagogic Translation] In La traducción a través de los tiempos, espacios y disciplinas, ed. S. Jansen and M. Schrader-Kniffki, 305-21. Berlin: Frank \& Timme.

Weissmann, D. 2012. La médiation linguistique à l'Université: propositions pour un changement d'approche [Linguistic Mediation at University: Proposals for a Change of the Approach]. Études de linguistique appliquée 167: 313-24.

Whyatt, B. 2009. Translating as a way of improving language control in the mind of a L2 learner: assets, requirements and challenges of translation tasks. In Translation in Second Language Learning and Teaching, ed. A. Witte, T. Harden and A. Ramos de Oliveira Harden, 181-202. Frankfurt: Peter Lang.

Widdownson, H.G. 2003. Defining Issues in English Language Teaching. Oxford: Oxford University Press.

Williams, C. 2012. The National Immersion Scheme Guidance for Teachers on Subject Language Threshold: Accelerating the Process of Reaching the Threshold. Bangor: The Welsh Language Board. 